\title{
CNS blastomycosis in a young man working in fields after Hurricane Katrina
}

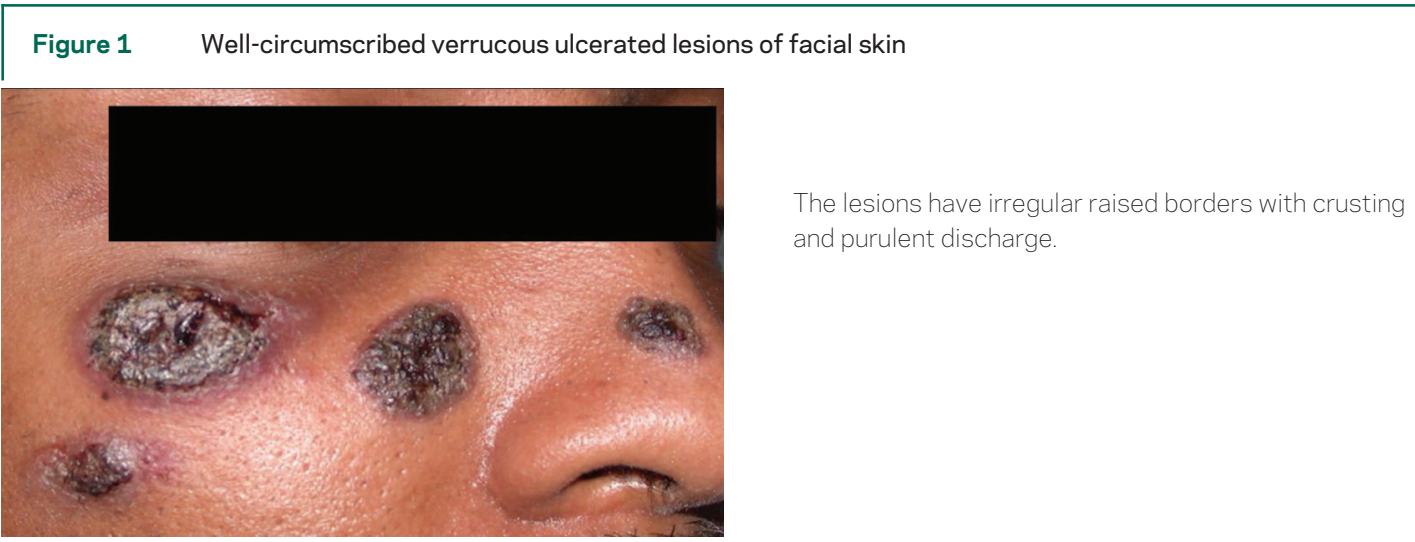

A 26-year-old man with a 3-month history of headache, fatigue, cough, fever, and hemoptysis despite empiric treatment with antibiotics presented with a spreading facial rash (figure 1) and decline in cognitive function. He reported working at a farm hit by Hurricane Katrina. A neurologic examination revealed ataxia and left sided weakness, and he required 20 to 45 seconds to answer questions and repetition of several commands. A chest X-ray showed bilateral infiltrates.

Given suspicion for systemic fungal disease, amphotericin B deoxycholate was empirically started. A skin biopsy revealed Blastomyces dermatitidis. A MRI of the brain showed multiple enhancing lesions (figure 2, A and B). Treatment was changed to amphotericin B lipid complex for optimal CNS penetration. ${ }^{1}$ The patient was discharged on itraconazole.

At a 4-month follow-up the neurologic examination normalized and skin and pulmonary lesions resolved. A repeat MRI (figure 2, C and D) showed a marked decrease in enhancing lesions. Itraconazole was continued for 1 year.

Viktor Szeder, MD, PhD; Santiago Ortega-Gutierrez, MD; Michael Frank, MD; and Safwan S. Jaradeh, $M D$, Milwankee, WI

Disclosure: The authors report no conflicts of interest.

Address correspondence and reprint requests to Dr. Safwan S. Jaradeh, Department of Neurology, Medical College of Wisconsin, 9200 W Wisconsin Ave., Milwaukee, WI 53226; sjaradeh@mcw.edu

\section{REFERENCE}

1. Cook PP. Amphotericin B lipid complex for the treatment of recurrent blastomycosis of the brain in a patient previously treated with itraconazole. South Med J 2001;94:548-549. 
Figure 2 Coronal (A, C) and sagittal (B, D) gadolinium enhanced T1 images
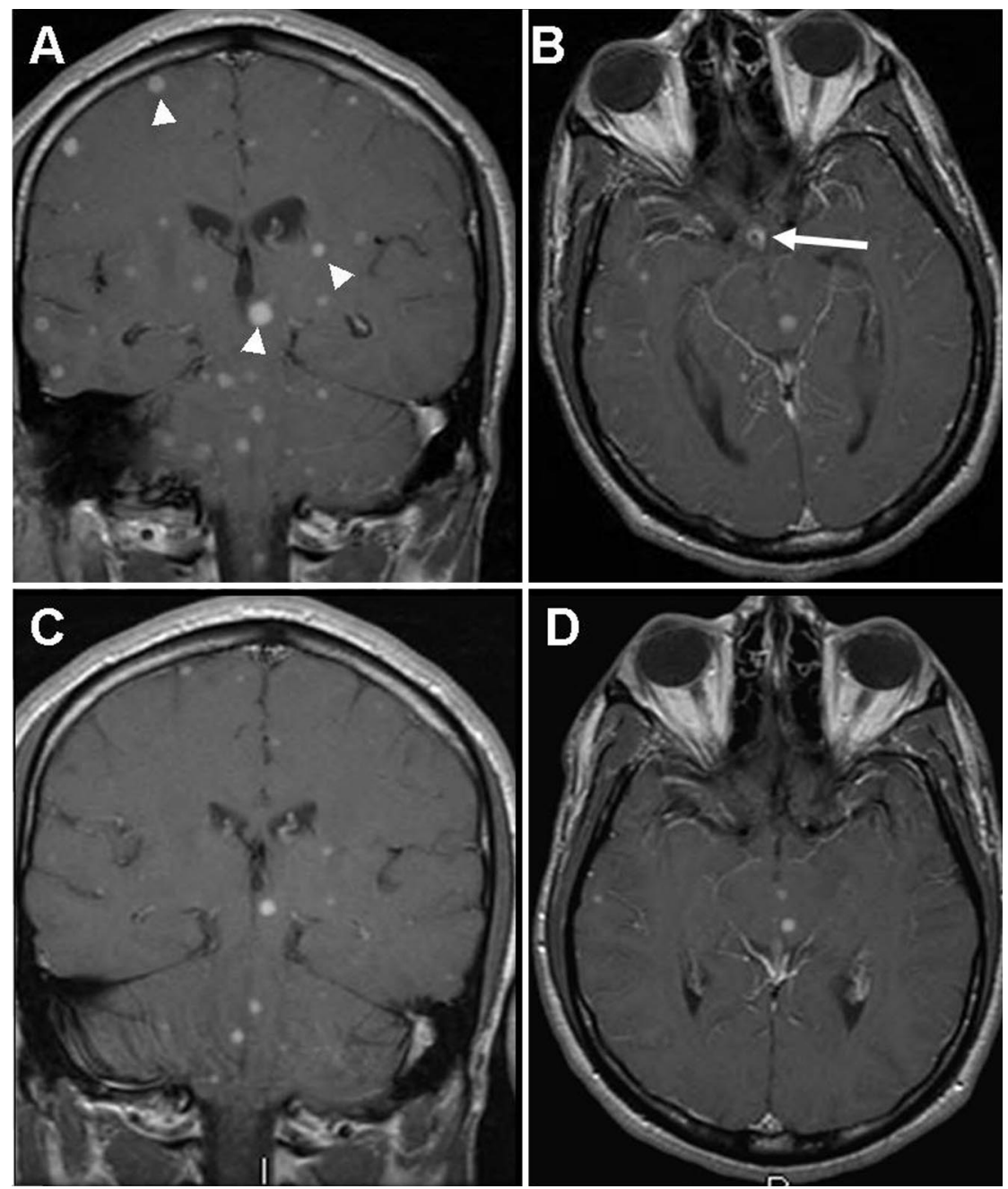

(A, B) Numerous spherical, intensely and homogeneously enhancing scattered supratentorial (gray/white matter junction), infratentorial (arrowheads), and brainstem lesions, consistent with hematogenous spread of blastomycosis. Note also the involvement of the proximal optic nerves and chiasm (arrows). (C, D) Follow-up imaging at 4 months shows marked reduction in the number and size of the enhancing lesions. 


\section{Neurology}

CNS blastomycosis in a young man working in fields after Hurricane Katrina

Viktor Szeder, Santiago Ortega-Gutierrez, Michael Frank, et al.

Neurology 2007;68;1746-1747

DOI 10.1212/01.wnl.0000265229.31844.45

This information is current as of May 14, 2007

\section{Updated Information \&} Services

References

Citations

Subspecialty Collections

Permissions \& Licensing

Reprints including high resolution figures, can be found at: http://n.neurology.org/content/68/20/1746.full

This article cites 1 articles, 0 of which you can access for free at: http://n.neurology.org/content/68/20/1746.full\#ref-list-1

This article has been cited by 1 HighWire-hosted articles: http://n.neurology.org/content/68/20/1746.full\#\#otherarticles

This article, along with others on similar topics, appears in the following collection(s):

Fungal infections

http://n.neurology.org/cgi/collection/fungal_infections

MRI

http://n.neurology.org/cgi/collection/mri

Information about reproducing this article in parts (figures,tables) or in its entirety can be found online at:

http://www.neurology.org/about/about_the_journal\#permissions

Information about ordering reprints can be found online:

http://n.neurology.org/subscribers/advertise

Neurology ${ }^{\circledR}$ is the official journal of the American Academy of Neurology. Published continuously since 1951, it is now a weekly with 48 issues per year. Copyright . All rights reserved. Print ISSN: 0028-3878. Online ISSN: 1526-632X.

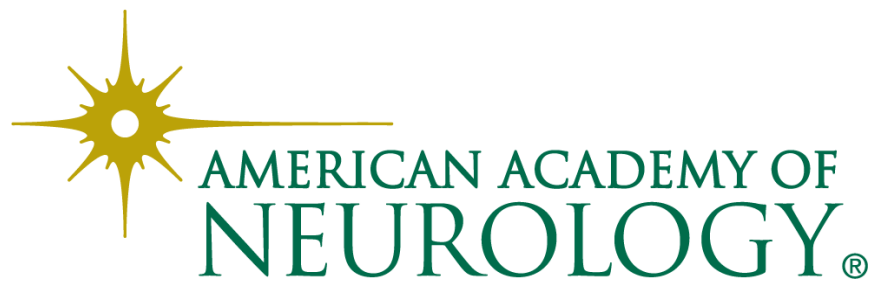

